\title{
METHODS OF DEVELOPING THE SYSTEM OF SPIRITUAL AND MORAL EDUCATION OF YOUNG STUDENTS THROUGH THE UZBEK PEOPLE'S PERFORMING ART
}

\author{
Khilola Tursunbaevna Botirova \\ Assistant Professor of Andizhan State University, Andizhan region, Republic of Uzbekistan
}

Article DOI: https://doi.org/10.36713/epra6721

DOI No: 10.36713/epra6721

\begin{abstract}
ANNOTATION
This article addresses the issues of arousing young students' interest in national songs, the ability to understand the ideas expressed through listening to national music, as well as the formation of students' taste in the selection of works.
\end{abstract}

KEY WORDS: value, ethics, etiquette, spirituality, education, upbringing, science, pedagogy.

\section{INTRODUCTION}

Scientific research on the development of young students' interest in artistic values has been conducted in the world's leading research centers and higher education institutions, including the American History Association (USA), the Institute named after Frica Baliet (Germany), the Institute of History Studies in Cambridge (UK), Institute of Historical Research ASOU University (South Korea), Institute of History of the Russian Academy of Sciences. Also, the training of competitive personnel through the formation of music culture in students (France), the systematization of training for the promotion of music culture in higher education (Argentina), the development of youth music culture on the basis of advanced, modern technologies, technological modernization (Australia) , mechanisms for improving the pedagogical basis for the formation of musical culture in students of higher education institutions (Kazakhstan). During the years of independence, a number of scientific studies have been conducted on this problem.

\section{METHODS}

From philosophers and sociologists S.Shermuhamedov, Q Nazarov, N.Kamilov, J.Tulenov, M.Imomnazarov, U.Koraboev,
A.Begmatov, M.Bekmurodov, I.Karimov, A.Umarov, A.Ochildiev, E.Yusupov , N.Juraev, T.Mahmudov, Z.Kafurov and others have studied in detail the spiritual foundations of human perfection, national and universal values, national ideas and ideology, national mentality, morality, ethics, independence and spirituality.

M.Ochilov, O.Musurmonova, S.Nishanova, S.Fayzulina, S.Annamuratova, U.Makhamov, F.Khalilov in their doctoral dissertations and scientific researches on spiritual and moral education of children, formation of spiritual culture of students, the idea of a perfect man in development of pedagogical thought, issues of education and upbringing in higher education institutions have been scientifically and theoretically studied.

\section{RESULTS AND DISCUSSIONS}

The use of samples of national musical heritage is covered in detail in research conducted by educators, art historians like T.G'ofurbekov, A.Jumaev, O.Ibragimov, F.Karamatov, G.Azimova, A.Nazarov, D.Rashidova, A.Odilov, M.Tairov, F.Vasilev, A.Leviev, M.Toshmuxammedov, A. Lutfullaev, F.Abdurahimova. The arousal of interest in national songs among young students, the ability to understand the idea expressed through listening to 
national music, as well as the the issues of formation of students' taste in the selection of works have been studied by S.Fayzulina, S.Annamuratova, F.Juraev, R.Tursunov, B.Lutfullaev, Q.Mamirov, X.Nurmatov, R.Qodirov, Sh.Janaydarov, F.Khalilov, Sh.Raximov, D.Qodirov, I. Reves.

Although scientists in Uzbekistan have conducted research on the development of the spiritual and moral system of students through the art of folk music, the development of geopolitical processes in modern conditions, the escalation of ideological struggles for the human mind and heart, the issues of ways to assimilate our musical heritage folk instruments in the rising generation through modernized didactic support as a factor of resilience have not yet been specifically studied [1.1.]

The activities of musicians and the features of their creative environment, the development of folk music, as well as the mood and other issues of "Shashmaqom" are described in the research of wellknown foreign art critics Joseph Elsner, Arthur Jung and Tony Levine [3].

The role of folk instruments in the development of the spiritual and moral qualities of a harmoniously developed generation on the basis of works of national music in the institutions of the world education system is invaluable [4].

In this regard, the United Nations Educational, Scientific and Cultural Organization (UNESCO) has registered the historical monuments, ancient cities, written and oral folk art, the International Music Festival of Oriental Songs, the great song and music "Shashmaqom" as an intangible heritage of mankind, repair of folk instruments, the study of the masterpieces of national music in the countries through the study of their methods are the indications of the special emphasis on its widespread promotion [5].

In order to create conditions such as teaching the basics of music, which is the heritage of our national music, to further improve the skills of instrumental performance, 4 maqom centers and maqom schools in 12 regions, regular competitions and festivals, as well as recordings of maqoms are being organized.

In order to attract and attract students to the art of music in our country the norms, material and technical base for holding the Republican competitions "Yagonasan Muqaddas Vatan", "San'at Gunchalari", "Khor Festival", "Ona Yurt Ohanglari", "Nafosat Gulshani" among higher educational institutions were created[6].

According to the Decree of the President of the Republic of Uzbekistan dated February 7, 2017 PF-4947 "Strategy of actions", "International Festival of Status", "International Festival of Bakhchis",
"Tashkent Spring", international festivals of opera and ballet are held. As a result, great conditions are created for students to increase their interest in the art of music. In particular, the Resolution of the President of the Republic of Uzbekistan on measures to "further develop the art of Uzbek national maqom" needs to be analyzed and reconsidered in the light of new requirements [2.2.] As a result, this resolution the idea of nurturing them as worthy heirs to the living music samples created by authors.

As a result, the essence of this decision lies the idea of educating the students and youth of our country as worthy heirs to the living music created by our ancestors.

Today, the upbringing of young people does not seem to be as important as the upbringing of their spiritual morals. We can also analyze and compare the youth of all countries and draw conclusions to clarify this issue.

What should we pay attention to in educating the younger generation of each country? First of all, it is a matter of listening to his heart and taking every point in the right way. The question naturally arises as to why one should listen to one's heart, because everyone needs a friend who is a sincere interlocutor who shows him the right way, and this friend is first and foremost his parents and mentor. Sometimes a cautious approach is required in the upbringing of young people. The interests and aspirations of the students will be immaculate, and if these actions are not encouraged or developed by the officials around them, the greatest decline will inevitably lead to the loss of these personnel.

First of all, approaching students with difficult but honorable way of life with examples of very beautiful life experiences, psychological influence and showing them the ways of its gradual development can be the basis for the researcher to follow the right path.

Encouraging all the scientific and practical creativity that students are doing gives great results.

At the same time, by showing the works of world composers, Western and Eastern thinkers, and showing the ways they have taken, the young generation will have effective results in their pursuit of their goals.

Today, one of the highest goals is to bring up the young generation as noble and patriotic. Just as the five hands are not equal, there are many talented people with intellectual knowledge among our young people, but it is clear to all of us that there are some among them who have not achieved these qualities. If we, the bureaucrats, do our job diligently, all the educated young generation, regardless of the country in which we live, will join the ranks of educated young people. As noted above, indifference 
leads the world to decline, and decline is the indifference of this younger generation. The future of countries with science-enlightened youth is bright. Indeed, science has no boundaries because it can be likened to a well being dug like a well, and it is difficult to see the end of science as the bottom is not visible as one digs a well. It is inevitable that every young generation will achieve the great goals set for them by studying and analyzing the works of our great thinkers, such as Abu Ali Ibn Sino, Babir Mirza, Mir Alisher Navoi, Fuzuli, Berdakh, Fitrat.

Another reform initiated by the President is the participation of young people in international competitions. It is no exaggeration to say that the results of this cooperation are bearing fruit, because the summary of these competitions is open to the creative activities of young people to make friends with the world, to make friends with each other, as well as to demonstrate scientific research and talent. if we say way, we are expressing our opinion correctly.

\section{CONCLUSION}

In conclusion, no one should stop in the pursuit of knowledge, and our students will have to follow the path of science with their own roadmaps, which will require all teachers to stand shoulder to shoulder. A responsible and caring approach to any work will inevitably lead to high results and results.

\section{REFERENCES}

1. [1] Zhuraev $F$. The direction and development of mass musical and aesthetic education of young students in the circles of Uzbek folk instruments. Diss. Author's abstract. Candidate of Pedagogical Sciences. T .. 1979.190; Azimov B. Legal education of youth by means of folk music. (on the material of amateur musical performances of vocational schools of the Republic of Uzbekistan): dissertation of the candidate of pedagogical sciences-T .: TDPU 1991, p. 188 .; Annamuratova S. Artistic and aesthetic education of schoolchildren in Uzbekistan. T .: Fan, 1991.S. 370; Zhanaydarov Sh.B. Amazing and international education of youth students by means of folk music. Aftoref. diss. cond. of pedagogical sciences. T .. 1991.S. 18; Khalilov F.N. Didactic foundations of instrumental-executive training of future music teachers. dissertation doc. of pedagogical sciences. $T$.: 2006.S. 216; Paluaniyazov P.K. The history of the musical culture of Karakalpakstan. (1925-1950) afteref. diss., doc. Cand. kst. sciences. Nukus, 2009; Ramanova S.B. Pedagogical bases of spiritual education of future music teachers on the basis of Karakalpak national musical traditions // diss., Ped.nauk. P.N. Uzbek Research Institute of Pedagogical Sciences named after Qori Niyazi. T .: 2005. B.
30-50; Porizhanova R.U. Traditions of aesthetic youth of the Karakalpak People's Pedagogy. Diss. Candidate of Pedagogical Sciences. T .. 2007.S. 118; Saidbekova S.S. Using the performing skills of the Karakalpak people in the education of schoolchildren. Diss., Doctor of Pedagogical Sciences. Toshkent State University of World Languages. T .: 2010.

2. Resolution of the President of the Republic of Uzbekistan "On measures for further development of the Uzbek national maqom art". People's Word newspaper. 2017. November 18th.

3. Khodjabaev A.R., Khusanov I. Methodology of vocational education. Tashkent. "Science and Technology", 2007.

4. Khodjabaev A.R. UMK for training a labor education teacher // Pedagogy. No. 10. 1990.

5. Khodjaboev A.R., Qosimov Sh.U. Methods of organizing and conducting practical vocational education. - Tashkent. 2007.

6. Khodjaboev AR Educational-methodical complex of training teachers of labor education. - $T$.: 1989 .-- 93 p.

7. M. Reuterstein. The basis of theoretical music knowledge. Moscow 2003.

8. Medushevsky V.V. Encyclopedia of the Young Musician. Moscow 1995.

9. A.Odilov. History of performance on Uzbek folk instruments. Tashkent 1995.

10. Historical essays by T.S. Vizgo "Musical Instruments of Central Asia" about fossils and artifacts. M., "Music" 1980.

11. O.Matyoqubov «Maqomot» T., «Music» 2004, 272-p.

12. I.Rajabov "On the issue of status", T., "Science" 1963.

13. A. Firdavsi, "Shohnoma" T., Publishing House of Literature and Art named after G. Gulom, 1984, p. 199

14. A. Fitrat "Uzbek Classik music and its history" M., 1926, T., 1993.

15. V. Belyaev "Musical Instruments of Uzbekistan" M., 1933.

16. F. Karomatov "Uzbek instrumental music" T., 1972.

17. I. Gruber. General history of music I. "Muzgiz", M., 1965, p. 4

18. Rahmonov M. Uzbek theater. From ancient times to the XVIII century. "Fan", T., 1975, 49-p.

19. Goibov G. Music and dances of the peoples of Central Asia before and after the Arab conquest // Borbad and artistic traditions of the peoples of Central and Western Asia: history and modernity. - Dushanbe, 1990. pp. 131-133.

20. Dzhumaeva A. Islam and Music // Music Academy, M., 1992, No. 3, p. 24

21. Musical aesthetics of the countries of the East. M., 1967, p. 271-272.

22. L.I. al Faruqi. Unity and Variety in the Music of Islamic Culture, op. cit., p. 177-178

23. Dadajonova I. IX-X centuries Musical culture of the peoples of Uzbekistan. Manuscript. 
24. Library of Art History. Inv.№1005, T., 2004, 14p.

25. Ziynat-al-majolis. Manuscript source. Inv.№4229. Pages 155-156. Fund of the Institute of Oriental Studies of the UzFA.

26. Rajabov I. Statuses. T., SAN'AT Publishing House, 2006, pages 15-16.

27. Al-Farabi, Abu Nasr. Kitab al-musiqa al-kabir. Cairo, 1967 (1208 pages)

28. Bakhta I.G., Romanovskaya E.E. Uzbek dance "Great play". Archive IIAN Uz, T (B), B-30, No. 247, $T(F)$, No. 398 